\title{
AS CONDIÇÕES SOCIAIS DE PRODUÇÃO DAS LEMBRANÇAS ENTRE IMIGRANTES UCRANIANOS
}

Paulo Renato Guérios

A "memória" é um objeto de estudo que se encontra na interseção de diversas disciplinas: a filosofia, a psicologia, a psicanálise, a história, as neurociências, a sociologia e a antropologia interessam-se por ela devido a diferentes motivos e com diferentes objetivos. Por estar situada "a cavaleiro" em várias áreas de conhecimento, a "memória" é tomada como um objeto privilegiado para quem se propõe a explorar novas possibilidades de diálogo entre diferentes disciplinas acadêmicas.

No entanto, uma tal riqueza de possibilidades é em geral acompanhada de uma imprecisão na definição do modo pelo qual se vai trabalhar um objeto tão arredio - visto que a própria definição do que se entende por ele em cada caso é problemática. As concepções e as questões definidas para o estudo da "memória" em cada um desses campos acadêmicos são muito diversas entre si: a "memória" dos psicanalistas não é a mesma "memória" dos neurocientistas, dos cognitivistas ou dos cientistas sociais. Apesar disso, esses vários saberes dialogam constantemente entre si, realimentando-se ainda com discussões que ocorrem fora dos círculos acadêmicos. As múltiplas interações que decorrem dessa circulação de idéias colocam em diálogo temas e problemas distintos, criando uma nebulosa semântica e temática virtualmente inesgotável ao redor do assunto.

Paradoxalmente, ao mesmo tempo vários fenômenos permanecem pouco explorados dentro de cada ramo acadêmico. Na história e nas ciências sociais, a "memória" tem servido desde a década de 1980 como um instrumento para falar das ações de construção identitária e das lutas pela definição de uma versão compartilhada do passado de um dado grupo social. ${ }^{1}$ Estas questões constituem apenas uma fração das problemáticas no que se refere à relação que os agrupamentos humanos estabelecem com seu passado.

Desse modo, por um lado, é necessário buscar uma maior clareza na definição dos problemas de pesquisa sobre a "memória" dentro de cada área do conhecimento, empreendendo esforços para desenvolver conceitos 
e instrumentos mais precisos; por outro, é possível examinar de forma mais detida algumas questões relacionadas aos fenômenos empíricos usualmente enquadrados sob esta rubrica.

O presente artigo parte da discussão de um estudo clássico sobre a "memória" nas ciências sociais: as obras acerca da "memória coletiva" escritas por Maurice Halbwachs (1976 [1925], 1968 [1950]). Talvez devido a seu grande sucesso, diversos autores consideram que elas esgotaram sua capacidade de emprestar legibilidade aos fenômenos observados. ${ }^{2}$ Nosso objetivo é propor um enfoque para a pesquisa que, inspirado pelo pensamento deste autor, dele se delimita ao realizar a crítica dos instrumentos e dos objetivos por ele definidos. ${ }^{3}$ Para tanto, serão utilizadas como material empírico as lembranças produzidas por imigrantes camponeses de origem eslava — os "rutenos" ou "ucranianos"4 — acerca de sua vinda ao Brasil no final do século XIX.

O artigo inicia-se com um estudo crítico das idéias de Halbwachs sobre as relações entre "memória" e "sociedade"; após uma breve apresentação dos imigrantes ucranianos, explora relatos de sua imigração para encetar uma discussão que envolve as condições sociais que infletiram a produção de suas lembranças; por fim, conclui-se com o exame de algumas implicações da análise aqui empreendida.

\section{Da "memória coletiva" às condições sociais da produção de lembranças}

Maurice Halbwachs (1877-1945) foi o primeiro sociólogo que analisou a vinculação entre a maneira específica pela qual um dado indivíduo lembra de seu passado e seu pertencimento social. ${ }^{5}$ Em Les cadres sociaux de la mémoire, seu primeiro livro, publicado em 1925, Halbwachs propõe que o ambiente social não é apenas o condicionador "externo" de uma memória de natureza "interna", mas que a própria estrutura interna da lembrança implica a preexistência da vinculação dos sujeitos com grupos sociais. $\mathrm{Na}$ introdução desta obra, o autor define "quadros sociais da memória" como "os instrumentos de que a memória coletiva se serve para recompor uma imagem do passado que concorde em cada época com os pensamentos dominantes da sociedade" (:vii). Esses "quadros" seriam então princípios de estruturação, combinados com imagens individuais específicas vividas pelo sujeito, que reconstroem e reorganizam as lembranças do passado de acordo com as exigências do presente.

Na obra de Halbwachs, os "quadros" sociais, que para ele regulam a evocação e a reconstrução da memória, aparecem como "moldes" exteriores 
que se impõem sobre os indivíduos, e que são criados e empregados por grupos também objetificados. Assim, existiriam quadros sociais da memória relativos à "família", aos "grupos religiosos" e às "classes sociais". Como afirma o autor,

Tendo reconhecido a que ponto o indivíduo é dependente da sociedade, é natural que consideremos o próprio grupo como capaz de se lembrar, e que atribuamos uma memória à família, por exemplo, assim como a qualquer outro conjunto coletivo. Isso não é uma simples metáfora (Halbwachs 1976 [1925]:146).

O estudo da "memória coletiva" aí proposto por Halbwachs é duplamente tributário da sociologia durkheimiana. Por um lado, ao formular o conceito de "quadros sociais da memória", ele deseja trazer para o campo da sociologia a "memória", um fenômeno atribuído pelos filósofos ao "espírito humano". Como afirma Namer (1987:33), o conceito de "memória coletiva" é "herdeiro de uma literatura filosófica do século XIX e da sociologia do conhecimento de Durkheim. O 'quadro social' é essencialmente para nosso autor um quadro mental à maneira de Durkheim, que fala dele a partir de uma tradição kantiana". Trata-se, portanto, para Halbwachs, de definir que os "quadros da memória" têm uma origem social, e não são um a priori do espírito. Ele inscreve-se assim em uma tradição mentalista: para ele, o movimento de rememoração é uma reconstrução do passado, que é operada por uma cognição humana moldada por forças sociais.

O projeto durkheimiano de Halbwachs, contudo, herda também algumas das limitações presentes na obra de seu mestre. Se todo o raciocínio de Durkheim supõe que os acontecimentos sociais se dão em momentos de "efervescência", emprestando grande atenção ao dinamismo criador dos agrupamentos humanos, muitas vezes o vocabulário utilizado por ele ruma no sentido oposto, prejudicando a acuidade de suas próprias observações. ${ }^{6}$ Esse vocabulário, herdado de filósofos intelectualistas, leva o autor a formular suas idéias como se uma "consciência de si" fechada em si mesma estivesse em permanente oposição a uma "sociedade" coesa, porém perturbada por "tensões sociais": como afirma Bastide (1970:82-83), ao definir a "memória coletiva", Halbwachs "reedita o velho problema durkheimiano da existência de uma consciência coletiva, exterior e superior aos indivíduos, na qual os indivíduos vêm se fundir para não serem senão sua emanação". Adicionalmente, na obra de Halbwachs o próprio grupo é portador de uma memória, ou seja, de uma faculdade individual. Ao fazer a resenha de Les cadres sociaux de la mémoire, já em 1925, Marc Bloch advertiu para o risco "do emprego, com o epíteto 'coletivo', de termos emprestados à psicologia 
individual" (Bloch 1925:78-79). Em um só golpe, assim, o termo "memória coletiva" homogeneíza o grupo e antropomorfiza-o ao atribuir-lhe faculdades individuais.

O objeto "memória coletiva", portanto, parece desde a sua definição criar mais dificuldades do que esclarecimentos para a compreensão dos mecanismos sociais ligados à percepção do passado: o termo "memória" remete a uma faculdade humana, uma categoria a priori do espírito humano, cujo portador seria um indivíduo moldado por um grupo antropomorfizado; o termo "coletivo" remete à homogeneidade de um grupo tido como totalizado, estável e imutável.

No entanto, podemos explorar as relações entre "memória" e "sociedade" a partir de um outro ponto de vista que está presente na própria obra de Halbwachs, mas que não é explicitado ou destacado como tal. Como demonstra Namer (1987:21-ss.), em vários momentos, ao utilizar o termo "memória", Halbwachs opera um deslizamento semântico em sua escrita. Este termo tem uma dupla acepção: por um lado, ele designa uma faculdade humana, a capacidade de recordar-se de eventos e situações passadas; por outro, designa também o conteúdo desses eventos e dessas situações, por exemplo, quando se fala que uma pessoa "escreveu suas memórias". Sem tratar esta distinção, Halbwachs utiliza o termo alternadamente em suas duas acepções. A questão é que a "memória" enquanto faculdade humana não é observável, ela é uma abstração. Ela é um instrumento conceitual que se refere à maneira pela qual as pessoas constroem e evocam suas lembranças. Como tal, ela apenas pode ser inferida a partir de um material empírico concreto, que são as lembranças dos sujeitos empíricos - estas sim observáveis. As hipóteses que Halbwachs levanta sobre o funcionamento da "memória" enquanto faculdade do espírito humano (ou seja, em sua primeira acepção) estão relacionadas às questões herdadas da filosofia do final do século XIX; já suas reflexões sobre as lembranças contêm observações valiosas para uma análise sociológica.

Por outro lado, Halbwachs opera um segundo deslizamento semântico quando utiliza o termo "coletivo". Em certos momentos de sua obra, esse termo diz respeito àquilo que pertence a um grupo social específico: a "memória coletiva" é aí um conjunto de lembranças partilhado entre os membros de um dado grupo. Em outros momentos, contudo, o termo "coletivo" refere-se aos elementos de caráter social atuantes quando um sujeito se lembra de algo. Nessas ocasiões, Halbwachs enfoca os constrangimentos sociais que atuam sobre a percepção do passado: o reforço de uma lembrança pelos outros, as pressões para que a versão corrente sobre o passado conforme-se às necessidades presentes, as inflexões nas lembranças devidas 
às referências de tempo e espaço reconhecidas e fixadas pelos homens de um determinado grupo.

Tendo em vista esta discussão, é possível redefinir a tarefa de uma "Sociologia da memória" a partir da própria leitura de Halbwachs: trata-se de, ao invés de definir como objeto uma "memória coletiva", cuja conceituação será sempre problemática, tomar como objeto a exploração dos constrangimentos sociais que operam sobre uma pessoa quando ela se refere a seu passado - ou, em outras, enfocar as condições sociais de produção das lembranças. ${ }^{7}$

\section{A existência de uma "memória coletiva" entre os descendentes de ucranianos}

Para estudar as condições sociais que infletem as lembranças dos membros de um grupo em um dado sentido, utilizaremos como material empírico os relatos produzidos pelos imigrantes "rutenos" ou "ucranianos" que vieram para as colônias do Paraná e Santa Catarina no final do século XIX acerca de sua vinda para o Brasil.

Realizei meu trabalho de campo em 2003 na cidade de Prudentópolis, que se localiza no centro-sul do Paraná, a $200 \mathrm{~km}$ de Curitiba. Ao iniciar minha pesquisa, eu vislumbrava a possibilidade de realizar um estudo comparativo entre as lembranças produzidas pelos próprios imigrantes sobre a sua vinda para o Brasil, encontradas nos arquivos locais, e os discursos partilhados hoje entre seus descendentes referentes às suas origens ucranianas e à migração de seus avós e bisavós. O fato de Prudentópolis ter se afirmado como o grande pólo de concentração dos membros desta etnia no Brasil, ostentando marcas explícitas de sua presença na ocupação de seu espaço e nos traços culturais da vida cotidiana ${ }_{1}^{8}$ indicava a possibilidade da existência de uma "memória coletiva" sobre a migração entre essa população.

No entanto, se as fontes de arquivo acerca da vinda dos rutenos ao Brasil efetivamente pareciam constituir um material propício para a análise da questão que eu propunha, meu trabalho de campo indicava o contrário. De fato, rapidamente percebi que em minhas interações com os colonos ${ }^{9}$ de Prudentópolis o assunto da vinda de seus antepassados ao Brasil jamais surgia espontaneamente. Ao encontrá-los pela primeira vez, eu me apresentava como um professor da universidade que estava fazendo pesquisa no município, o que bastava para que iniciássemos uma longa conversa. Nelas, eles tratavam de temas variados de seu cotidiano, e as referências à "Ucrânia", a "ucranianos" ou a "brasileiros" eram muito raras — e, como 
assinalei, referências à vinda de seus antepassados para o Brasil não chegavam a ser feitas. Se eu próprio elaborava uma pergunta a esse respeito, era imediatamente encaminhado às pessoas que "sabiam dessas coisas" - em geral os moradores mais idosos de cada colônia ou os religiosos.

Isto indicava claramente que a migração ou a história da comunidade não era assunto que fazia parte dos interesses cotidianos dos colonos. Esse tipo de situação é bastante comum, mas não é difícil encontrar trabalhos sobre "memória coletiva" que se baseiam apenas nos depoimentos de "especialistas" locais acerca do passado, e que atribuem os conteúdos desses depoimentos à "comunidade" como um todo: as lembranças dos "especialistas" são em geral tratadas como elementos de uma "memória coletiva" portada pelo grupo como um todo, mas melhor conhecida e dominada por alguns de seus membros. O fato, contudo, é que a importância desses assuntos na vida cotidiana dos colonos de Prudentópolis era bastante restrita, e que postular a existência de uma "memória coletiva" sobre seu passado "ucraniano" seria um ato arbitrário do pesquisador, já que tais assuntos surgiam apenas como um efeito de minha presença e de meu interesse em perguntar sobre esse passado.

Uma das maiores dificuldades de fazer uma pesquisa sobre a "memória" em uma dada comunidade é certamente criar uma démarche de pesquisa que evite que o próprio pesquisador seja determinante na definição da existência e do conteúdo de um saber compartilhado entre seus pesquisados sobre o passado. Este problema aparece, por exemplo, no trabalho de Lavabre (1994) sobre a "memória" dos militantes comunistas, apesar de toda a atenção e de todo o cuidado da pesquisadora a respeito. Ao entrevistar os militantes do Partido Comunista Francês, Lavabre preocupou-se em elaborar suas questões de forma extremamente cuidadosa para interferir o mínimo possível na resposta de seus entrevistados, e para que suas perguntas não os conduzissem em uma direção predeterminada pela própria pergunta.

Tomemos um exemplo de seu texto para demonstrá-lo. A historiografia oficial do Partido Comunista Francês empresta grande importância ao seguinte evento: em 1956, a direção do Partido soube das violências perpetradas por Stalin na União Soviética, mas resolveu não reagir a essa informação por "incredulidade e vontade de ocultação, confusão e cálculo, comoção e preocupação de justificar o injustificável em nome da necessidade histórica" (Lavabre 1994:123). Vinte anos após, surgiu a "tese do atraso de 1956": teria sido devido a essa decisão que o Partido nunca havia conseguido crescer conforme sua expectativa, por ter insistido na tese da "ditadura do proletariado" e por não ter procurado abrir uma "via francesa" (e não soviética) para chegar ao comunismo. Com esse elemento 
da história oficial do Partido Comunista Francês em mente, Lavabre partiu para entrevistar os militantes comunistas preocupada em não formular uma pergunta diretiva a respeito do evento de 1956, para "não ter como pressuposto a presença do tema na memória deles". Assim, sua pergunta era: "em sua opinião, o que parece ter tido importância na história do Partido Comunista Francês?" (1994:123).

Nas entrevistas com os militantes, o tema do "retardo de 1956" não surgia espontaneamente, o que a fez concluir que esta tese "não penetrou sua reflexão". Mais do que isso: quando apresentava a tese a seus entrevistados, eles ficavam "perplexos diante de uma elaboração teórico-histórica estranha à sua reflexão ou muito sofisticada para suas competências" (1994:125).

Contudo, ao organizar sua estratégia de pesquisa para estudar a "memória viva" dos militantes, Lavabre propôs primeiramente "colocar em evidência os canais pelos quais se elaboram e se difundem a história oficial e o 'dever de memória' prescrito aos militantes" para, em seguida, "dar-se os meios de decidir se há ou não adequação entre essas imagens do passado e aquelas que se forjam e que veiculam os indivíduos" (1994:30, ênfase minha). No momento em que definiu dessa forma seu objetivo, toda a sua preocupação e o seu cuidado em não interferir na resposta de seus entrevistados foram perdidos, pois a história oficial do partido (o "dever de memória") passou a agir como o único parâmetro a partir do qual ela poderia enxergar as memórias individuais (a "memória viva dos militantes").

A análise da "tese do retardo de 1956" levou Lavabre ao entendimento de que "não é possível concluir que existe memória coletiva porque existe na história vivida um evento que pode ser considerado marcante" (1994:159). A raiz do problema, contudo, está no fato de que o evento é "considerado marcante" pela direção do partido. Se a memória oficial é tomada como parâmetro, a única coisa que pode ser descoberta efetivamente é o quanto a "memória viva" se aproxima ou se afasta dela. Ao invés de perguntar sobre quais são os conteúdos da "memória viva" e, principalmente, sobre o porquê dos conteúdos dessa "memória" serem esses e não outros, a formulação de sua questão de pesquisa apenas lhe permitiu descobrir que a "memória individual" não se conformava à memória oficial - hipótese que, afinal, era o ponto de partida de sua problemática.

Em meu caso, as lembranças acerca da vinda dos rutenos para o Brasil eram abordadas a partir de um riquíssimo material empírico: os diferentes relatos disponíveis que haviam sido escritos pelas pessoas que migraram, mas que não faziam parte da "memória viva" (nos termos de Lavabre) de seus descendentes — os colonos de Prudentópolis que eu entrevistava em 2003 ou seja, não eram lembranças significativas para eles, estando restritas a 
alguns especialistas. Eu não poderia então colocar em primeiro plano meu interesse sobre a migração em minhas entrevistas, ou incorreria no risco de, assim como fez Lavabre, utilizar uma referência exterior como parâmetro para compreender as dinâmicas da "memória" entre esses colonos.

Entretanto, como afirmado acima, os relatos dos rutenos que migraram para o Brasil, que foram publicados em língua ucraniana principalmente nos jornais e nos periódicos religiosos da etnia, pareciam propícios ao trabalho aqui proposto. Assim, o estudo sobre as condições sociais da produção de lembranças restringiu-se à análise desse material empírico. O corpus aqui utilizado para análise compõe-se de: a) um documento contemporâneo à migração: a carta escrita em 1897 por Teodor Pototskei, ruteno que se instalou na colônia de Rio Claro, em resposta a um contato feito pelos migrantes de origem rutena que foram para os Estados Unidos. Os colonos da América do Norte desejavam informar-se acerca das condições de estabelecimento dos migrantes no Brasil, e Pototskei produziu um relato detalhado dos esforços que estavam sendo feitos para a construção de sua colônia; b) relatos feitos por alguns colonos de origem rutena décadas após sua chegada, nos quais eles reconstroem suas lembranças acerca da decisão de partir, da vinda para o Brasil e dos primeiros anos vividos nas colônias paranaenses. Dentre eles encontram-se a breve autobiografia de Luca Morski (1914), escrita para seus filhos; o artigo redigido por Andrei Hotsailiuk (1924) para o jornal Pratsia, de Prudentópolis, no qual ele se colocava ao lado dos sacerdotes uniatas em uma disputa que ocorria com os membros da intelligentsia leiga da etnia na época, e em que ele se esforçava por demonstrar a relevância do trabalho dos missionários quando das instalações das colônias - deste artigo, interessam-nos os trechos em que ele fala de sua viagem de vinda ao Brasil; os depoimentos de Pelep Kobren, Paulo Muzeka e Mehailo Cheutchuk acerca de suas viagens ao Brasil, escritos em 1935, como parte das comemorações dos 40 anos do estabelecimento das colônias; e c) por fim, o artigo escrito em 1951 por um dos primeiros migrantes rutenos a chegar ao Brasil, Ivan Pacevitch, feito em um registro memorialista e convidando outros migrantes a "deixar um pequeno fragmento de lembrança" para "escrever a história de nossas colônias ucranianas no Brasil" (Pacevitch 1951).

Todos estes textos tinham, apesar de suas diferenças de registros (depoimentos, relatos, testemunhos), um enquadre autobiográfico e um mesmo enfoque: a descrição das lembranças da vinda ao Brasil e dos primeiros anos nas colônias. Importa-nos aqui compará-los entre si, visando às suas semelhanças e diferenças ao tentar cumprir esta mesma tarefa. ${ }^{10}$ 


\section{As convergências entre relatos de imigrantes rutenos sobre sua vinda ao Brasil}

Como vimos, ao fundamentar sua "Sociologia da memória", Maurice Halbwachs parte do pressuposto durkheimiano de que a vida em sociedade constrange os indivíduos a se comportarem de acordo com as normas estabelecidas pelo grupo em que estão inseridos, e que sua "memória" não escapa a esta dinâmica.

De fato, a percepção dos rutenos acerca da possibilidade de mudar para a América foi constituída a partir de alguns fundamentos básicos em comum: além de terem uma longa história passada, partilhavam também pressupostos sobre o mundo que os rodeava e, conseqüentemente, um olhar específico a respeito das novas informações com as quais tinham contato. Ao perceberem os eventos que ocorriam na época da migração e ao reconstituí-los em um texto escrito anos mais tarde, os camponeses rutenos tinham seu olhar infletido de acordo com parâmetros que foram aprendidos e estabelecidos por eles mesmos e por seus ascendentes em inúmeras interações cotidianas. Vejamos alguns elementos dessa história partilhada.

No final do século XIX, os camponeses rutenos que viviam na Província da Galícia, no Império Austro-Húngaro, estavam nestas terras há várias gerações. Sua localização geográfica precisa foi essencial para a definição de sua posição diante de outros estratos sociais.

O território que os rutenos deixaram ao vir para o Brasil está no limite oriental da Europa. A história da ocupação dessa área é objeto de inúmeras controvérsias e é contada, a partir das poucas fontes disponíveis, de diferentes formas. Interessa-nos destacar dois elementos incontroversos acerca dessa história e que tiveram importância para a definição do perfil social dos camponeses rutenos do final do século XIX.

O primeiro elemento é a presença do rito grego da religião ortodoxa na região. Segundo Omelian Pritsak (1981, passim), um medievalista especialista na região, algumas crônicas medievais do século IX relatam o estabelecimento de um centro dinástico chamado Rus' às margens do rio Dnieperlocal onde hoje se situa a cidade de Kiev, atual capital da Ucrânia. Até o século XIII, o rio Dnieper era a principal rota existente de comércio entre a Europa Ocidental e Bizâncio (Constantinopla), então capital do Império Romano Oriental. Devido à localização estratégica do centro dinástico Rus' de Kiev, foram estabelecidos intercâmbios econômicos e culturais com Bizâncio. Como parte desses intercâmbios, no final do século $\mathrm{X}$, o príncipe Volodêmer converteu seus súditos ao cristianismo bizantino de rito grego, que se transformou na religião ortodoxa após o Cisma de 1054. O rito dessa 
religião manteve sua relevância como marcador social e como referência essencial para as condutas dos camponeses da região por vários séculos.

O segundo elemento é o fato de a Província da Galícia fazer parte de um Império multiétnico, o Império Austro-Húngaro. A região da Europa Oriental foi palco de inúmeras disputas ao longo dos séculos. A partir do século XIII, o centro dinástico Rus' dividiu-se em vários zemli, pequenas principalidades autônomas submetidas a constantes disputas internas e com seus vizinhos. Com o enfraquecimento e o colapso das principalidades Rus', a área do atual território ucraniano passou a constituir uma região de fronteira entre grandes Impérios. Seguiram-se séculos de marcante descontinuidade política: sabe-se que as disputas pelo controle da região envolveram o Império Otomano, o Khanate mongol da Criméia, a commonwealth lituano-polonesa, os Hetmanates cossacos e o czarado de Moscou. A partir de 1772, dois Impérios finalmente conseguiriam impor seu domínio sobre a região, configurando uma situação política que seria mantida até a Primeira Guerra Mundial: a porção oriental do atual território ucraniano tornou-se parte do Império Russo, enquanto as terras da Galícia tornaram-se parte do Império Austro-Húngaro.

Estes dois elementos - a presença do rito oriental e a convivência multiétnica em meio a disputas de poder entre Impérios - combinaram-se para emprestar uma configuração específica à população da região e ao contato entre os diferentes grupos que nela habitavam. Ao longo dessas disputas, os estratos dominantes foram aos poucos sendo assimilados política e culturalmente pelos sucessivos Impérios que se alternavam em seu comando, enquanto os estratos dominados mantinham sua língua de origem e a filiação à Igreja Ortodoxa. Como resultado, no início do século XVI o rito oriental era marca distintiva de pertencimento ao estrato dos servos feudais na região, enquanto os nobres falavam a língua polonesa e professavam o rito latino da Igreja Católica Romana. ${ }^{11}$ Foram esses servos, cujos principais marcadores étnicos eram seu pertencimento religioso e a língua própria, que passaram a ser chamados de "rutenos" a partir do século XVIII.

A posição social partilhada pelos rutenos e constituída no decorrer desse processo histórico é o principal elemento responsável pelo surgimento de convergências das lembranças de diferentes imigrantes dessa região que escreveram sobre a sua vinda para o Brasil. De fato, verifica-se que, apesar de todas as diferenças existentes entre os relatos disponíveis desses camponeses, em vários momentos há elementos comuns entre eles. Certos assuntos são recorrentes, eventos diferentes são muitas vezes descritos de maneira similar, e determinadas percepções sobre as novas experiências vividas nesse processo repetem-se em diversos relatos. 
Ao falar da vida na terra natal no contexto do discurso sobre a vinda para o Brasil, por exemplo, as marcas da horiá (горя, "fardo") e da bidá (біда, "miséria") aparecem repetidamente em diferentes testemunhos:

Nos primeiros dias de julho do ano de 1896 nos despedimos de uma vez por todas da aldeia em que nascemos, Ostalovetchi, no distrito de Peremechliane; expulsou-nos de nossa terra nativa a miséria, a pobreza e as dificuldades, buscando no então famoso Brasil um destino melhor e a felicidade (Kobren 1935).

Um dia durante as férias chegou meu pai e trouxe-nos uma novidade inesperada, que nós também viajaríamos para o Brasil, explicando-nos que tínhamos que ir para outro país procurar um melhor destino e a felicidade, pois aqui não há saída, é a miséria, e não há terra na qual trabalhar (Cheutchuk 1936).

De outra parte, quando o assunto é o objetivo buscado com a migração, há palavras que estão também sempre presentes quando esses migrantes falam de sua experiência. São elas chtchástia (щастя, "felicidade" ou "alegria"), lipcha dólia (ліпша доля, "destino melhor"). Em seus depoimentos, pensar sobre a migração é seguir esse contraste: de um lado, o passado na terra natal, a bidá, a horiá; de outro, o Brasil, a chtchástia, a lipcha dólia (Kobren 1935; Cheutchuk 1936).

Ao se expressarem dessa forma, os rutenos não apenas dizem que era necessário mudar-se para escapar à pobreza e à falta de perspectivas; eles o dizem sempre da mesma maneira e com o uso das mesmas palavras. Este contraste é assim muito mais do que uma mera informação ou um simples jogo de palavras: os rutenos estruturam seus relatos a partir de um modelo preexistente de compreensão dos eventos, um caminho conhecido e muitas vezes trilhado, que é empregado nas argumentações sem que tivesse sido anteriormente objeto de reflexão. Nesse modelo — um modelo dualista — os dois lados contrastantes da argumentação são estanques, completamente isolados, e têm valores opostos. O olhar lançado por eles sobre o passado é assim tributário de esquemas compartilhados de percepção da realidade que já estavam ativos antes da migração.

Os pesquisadores que tratam de mecanismos de regulação social do passado costumam tomar como casos de estudo comunidades que contam com uma organização responsável por apresentar uma versão "oficial" desse passado e por assumir atitudes que aproximem entre si versões potencialmente conflitantes acerca de eventos considerados importantes nesses grupos. Lavabre (1994), por exemplo, ao fazer a "sociologia da memória" do Partido Comunista na França, confrontou a memória oficial do partido com aquilo que chamou 
de "memória viva" dos militantes comunistas para "apreciar a influência da elaboração de uma historiografia partidária — que chamaremos de "memória histórica" - sobre as lembranças e as representações de passado que restituem os militantes" (1994:18). Já o estudo de Pollak (1990:244-247) sobre os relatos de ex-prisioneiros de campos de concentração nazistas, ao interrogar-se em certo momento sobre a formação de uma memória coletiva nesse grupo, trabalhou com a memória que foi constituída sob o enquadramento de associações de deportados: a existência de uma versão oficial acerca da "shoah" levou a um controle sobre o que poderia ser dito a seu respeito - os discursos históricos sobre o evento deveriam ser controlados a serviço da luta contra o esquecimento e, desse modo, as lembranças deveriam concordar com a versão "oficial" dos fatos - a "memória coletiva" tornou-se um "dever de memória".

Em ambos os casos, uma organização tomou para si a tarefa de construir fundamentos comuns a partir dos quais todas as lembranças referentes a um evento deveriam ser enunciadas. Exemplificando o que Hartog e Revel (2001) chamam de "usos políticos do passado": as lembranças dos militantes comunistas e as dos ex-deportados estiveram sujeitas à regulação social por parte de organizações formais (o Partido e as associações de deportados), que elaboraram uma versão "correta" e "aceita" dos fatos vividos pelos membros de cada uma dessas redes para que o passado pudesse ser utilizado apropriadamente no jogo social estabelecido com outros grupos.

O que chama a atenção nos relatos de viagem dos rutenos para o Brasil é que as recorrências entre os discursos ocorrem mesmo sem intervenções externas de uma organização desse tipo. A presença ubíqua da oposição chtchástia $\mathrm{x}$ bidá é um dos indicativos da existência de uma série de categorias compartilhadas entre eles que aproximaram suas percepções acerca da vinda para o Brasil, ${ }^{12}$ e permite supor que essas categorias sejam constitutivas de um "esquema de percepção" por meio do qual os indivíduos que pertencem a essas configurações sociais interpretam as situações com as quais são confrontados. ${ }^{13}$ Assim, nossa hipótese é a de que o esquema de percepção compartilhado pelos rutenos que nos escrevem seus relatos, e que foi estruturado a partir de categorias como chtchástia e bidá, é um dos elementos que aproximam entre si as lembranças dos migrantes.

Ao mesmo tempo, outros elementos recorrentes nos depoimentos colocam em destaque a intensidade da experiência religiosa enquanto fonte de parâmetros que serviram de referência à reconstrução do passado operada por estes atores sociais. Um primeiro exemplo da recorrência de esquemas de percepção ligados à experiência religiosa do grupo diz respeito ao uso das efemérides do calendário religioso como referência para localizar os eventos relatados. 
Eu saí no ano de 1895, após a Ressurreição de Cristo, no Providnu Subótu [dia em que Jesus reapareceu após sua ressurreição], de Mechkaliu, perto de Lviv (Pototskei 1897).

Um dia antes da Navetchéria Bohoiavlênia [dia do batismo de Cristo no rio Jordão, 7 de janeiro] partimos adiante em viagem (Hotsailiuk 1924).

Agora volto a escrever sobre minha família, porque aqui está a causa de minha partida para o Brasil. Quando eu tinha 12 anos, minha avó faleceu no próprio dia de Santo André. [...] e, na Uspênia máteri Bojoii [Assunção da mãe de Deus], minha mãe (Muzeka 1936)

Todas as vivências importantes para o processo migratório são referenciadas a datas do calendário religioso - e esta marca é recorrente em todos os depoimentos. Por um lado, como afirma Halbwachs (1976 [1925]:80) com base nas idéias de Durkheim, todos os grupos humanos constrangem seus componentes a perceber o tempo de uma mesma forma:

A vida em sociedade implica que todos os homens tenham um acordo sobre o tempo e as durações, e conheçam bem as convenções de que eles são objetos. É por isso que há uma representação coletiva do tempo; ela concorda sem dúvida com os grandes fatos de astronomia e de física terrestre, mas a esses quadros gerais a sociedade sobrepõe outros que concordam sobretudo com as condições e os hábitos dos grupos humanos concretos.

Ao tratar da "memória coletiva", Halbwachs considera que representações coletivas sobre o tempo, tais como o calendário religioso a que recorrem os rutenos em seus depoimentos, servem para essa "memória" enquanto pontos de referência para o que chama de "localização das lembranças", ou seja, como uma técnica de evocação de fatos passados: "O tempo nos importa aqui apenas na medida em que nos permite reter e lembrar dos eventos que foram nele produzidos" (1976 [1925]:94).

Em alguns momentos, contudo, a referência a Deus e aos Santos manifesta-se nos textos dos rutenos como mais do que um marco temporal. Ao apresentar sua leitura a respeito da conjunção de interesses que possibilitou a existência da migração, por exemplo, Kobren atribui a Deus a idéia e as iniciativas que o iniciaram:

A viagem pelo mar e a comida no navio não nos custaram nada. Por tudo isso pagou o governo brasileiro. E aqui, no lugar em que ficamos três semanas, nos deram 
de comer às custas desse governo. Enquanto, quando nós saímos da terra natal, éramos pobres, miseráveis, sem casa e famintos, aqui esse Brasil nos recebeu, deu pão e distribui terra. E assim o Senhor Deus nos concedeu não morrer miseráveis. A terra, que não tínhamos no País Natal, por vontade de Deus achamos aqui no Brasil. Digo "por vontade de Deus" porque há milhares de anos atrás, ainda no Velho Testamento, foi falado o Senhor Deus: "quando os pobres chorarem por mim — eu ouço seu choro - porque sou misericordioso", e disse ainda Deus: "Minha é a terra - e todo o universo é meu". Assim, portanto, escutou Deus a miséria, o fardo e as dificuldades de nosso pobre povo e conduziu-o para a terra brasileira, dando-lhe através do governo do país a terra. Porque a terra do Senhor é uma, tanto de um lado do oceano quanto do outro (Kobren 1935).

Kobren assimila um evento novo - a possibilidade de migrar e ocupar terras livres - a histórias da Bíblia que já conhecia, o que o leva a atribuir a existência dessas terras, o processo de viagem, o transporte e sua ocupação à ação de Deus: em todos os momentos, era Ele quem guiava o povo ruteno em direção ao Brasil. Ao relatar seu passado, Kobren estrutura suas lembranças a partir do emprego da linguagem religiosa, contando a história da migração de seu povo como a história das concessões de um Deus onipotente.

Podemos então formular a hipótese de que a recorrência do emprego de categorias religiosas nos relatos dos rutenos guarda uma significação adicional: as datas e outras referências religiosas não são apenas um guia para a periodização das lembranças, mas também um fator essencial para a configuração do próprio conteúdo dessas lembranças. Ao realizar seu estudo sobre a memória entre os judeus, Josef Yerushalmi chama a atenção justamente para este aspecto quando trata do emprego do calendário religioso por parte de seus sujeitos de pesquisa:

Uma simples lista de observância de aniversários não nos ensina nada daquilo que queremos saber. [...] Porque o verdadeiro problema não é tanto saber o que ajudava a estimular a memória coletiva, quanto conhecer a dinâmica mesmo da memória. Ora, esse é o ponto mais difícil de ser percebido. Os dias santos, os ritos, as liturgias são como partituras musicais. Em si mesmas, elas não nos restituem nem as nuances nem a materialidade de uma interpretação. Nós sabemos da extrema dificuldade que existe para tentar detectar aquilo que foi vivido interiormente. Entretanto, nós podemos nos arriscar a identificar aí várias características que interessam aqueles que estudamos (Yerushalmi 1984:58).

Assim como acontece com os judeus estudados por Yerushalmi, para os rutenos os esquemas de percepção ligados à sua filiação religiosa podem 
funcionar como muito mais do que pontos de referência para a localização de lembranças. Ao descreverem as passagens da vinda para o Brasil em estreita relação com o calendário religioso, eles fazem mais do que referenciar os eventos no tempo: eles assimilam as vidas dos Santos e os eventos do Evangelho à sua própria existência. Assim, Deus e os Santos aparecem como que presentes em todos os momentos da migração, participando ativamente dos acontecimentos e interferindo no destino que foi vivido no passado: suas lembranças são, em várias ocasiões, as lembranças de como Deus os acompanhou ao longo de sua viagem - e esta é uma marca essencial de seu pertencimento social. A apreensão da migração é então mediada por esses esquemas de percepção, que foram conformados pela vivência religiosa específica a essa configuração social.

\section{O surgimento de divergências entre os relatos}

Visto que os rutenos relatavam seu passado com o uso das mesmas categorias e os mesmos esquemas de percepção, seria então pertinente supor que eles eram portadores de uma "memória coletiva" única acerca desses eventos?

Ao contrário, como também afirmamos na Introdução, esta é justamente uma das limitações do conceito de "memória coletiva" de Halbwachs: a idéia subjacente de que a "memória" - enquanto conjunto de lembranças - é homogênea em um "grupo" ou "classe social". De fato, se algumas condições contribuem para infletir as lembranças dos membros de uma dada configuração em um mesmo sentido, outras concorrem para criar divergências entre as percepções desses acontecimentos. Tentar compreender o funcionamento das condições sociais de produção de lembranças não implica então afirmar que tais lembranças tendem a ser homogêneas para pessoas pertencentes a uma mesma configuração social.

Assim, se o objetivo de nosso estudo é colocar em evidência as condições que favorecem o surgimento de inflexões nas lembranças dos indivíduos ligados a certa configuração social, é necessário destacar que estas inflexões podem ocorrer em diferentes direções, ou seja, as lembranças podem aproximar-se ou afastar-se umas das outras. Abordemos então os mesmo relatos com o intuito de observar alguns princípios que facilitam o surgimento de divergências em suas percepções desses eventos.

Em 1936, quando Pelep Kobren decidiu registrar as lembranças de sua vinda para o Brasil, ele tratou da viagem de navio que fez entre Gênova e o Rio de Janeiro em 1896, relatando uma jornada que foi, em sua maior parte, amena e tranqüila: 
E o que as pessoas faziam no navio durante esse tempo? [...] De dia as pessoas ficavam no convés do navio, como formigas no formigueiro. [...] Todos os dias davam-nos de comer 3 vezes, e nessa função gastava-se bastante tempo. A comida era boa e saborosa, mas as pessoas não comiam muito, porque se gastava muito tempo nisso. Alguns não comiam nada por causa do enjôo. [...] O resto do tempo era gasto de diferentes maneiras. Alguns descansavam e contavam histórias. Havia alguns ótimos contadores de histórias entre nós que em três semanas de viagem não acabaram com seus repertórios. Alguns liam ou escreviam cartas. Outros se divertiam jogando cartas, dominó ou tocando violino. Alguns ficavam no convés e observavam o oceano, a água, o navio e os peixes. [...] Assim passavam os dias, um após o outro. [...] Nosso povo cantava. Assim começou: uma ou duas pessoas no começo. Logo 100 ou 200 pessoas se juntavam. [...] e assim cantavam sem dirigente, sem ensaio prévio, e era bonito que dava gosto de ouvir. "E o que cantavam?", pode perguntar algum cantor. Cantavam tudo o que sabiam! Além dos cantos de igreja, santos, cantavam "Juro j moiá, juro", "Pani mala, pana Petrucha kohala", "Tchumatchenka", [cantigas populares, conhecidas como kolomeikas] e assim por diante (Kobren 1935)

A viagem de Kobren, pelo tom com que é relatada, poderia quase ser confundida com uma viagem de lazer, cheia de distrações e amenidades. Ela não é muito diferente do registro feito por Mehailo Cheutchuk, que nos conta uma jornada tranqüila, de curiosidades e descobertas. Ele lembra do roteiro das diversas cidades pelas quais seu grupo passou, do movimento nas hospedarias, da chegada na Itália, e relata a instalação no navio do seguinte modo:

Ao entardecer saímos para o navio. Era outubro, e o sol ainda esquentava bastante. À noite, fomos distribuídos no navio para dormir [...] De manhã começamos a ouvir um ruído no navio. Nós atravessamos para o convés, olhamos ao redor, e já estávamos em pleno mar. Não se via nem a cidade, nem terra, apenas... céu e uma longa extensão de mar (Cheutchuk 1936).

A partida de Cheutchuk foi tão despreocupada que ele apenas percebeu que o navio havia deixado o porto quando já estava em alto mar. Seu relato segue com comentários diversos sobre a comida a bordo, os enjôos por causa do balanço do navio, a gentileza da tripulação italiana, e o surgimento de ilhas de vez em quando, onde o navio fazia escalas. E assim conclui seu relato, passando a impressão geral de que a vinda ao Brasil foi quase um passeio.

Já Andrei Hotsailiuk, ruteno que se instalou na colônia de Prudentópolis um pouco após Cheutchuk e Kobren chegarem ao Brasil, escreveu em 
1924 um relato bem mais sombrio acerca de sua viagem. Ele se lembra de sua vinda da seguinte forma:

No dia 11 de janeiro de 1896 nos trouxeram ao porto e subimos no navio. [...] No dia antes da Navetchériem Bohoiavlênia [dia santo comemorado em 15 de janeiro] partimos adiante. À noite caiu terrível tempestade. O navio oscilava para o alto e para baixo, todos tiveram enjôo e pagaram ao mar seu primeiro imposto. A tempestade durou meio dia, e após veio a calmaria. Mas então surgiu no navio um surto de sarampo e crianças morreram. Nossa viagem durou 22 dias, não passando quase nenhum sem mortes. Durante o período da viagem morreram 21 crianças e uma senhora idosa (Hotsailiuk 1924).

Do mesmo modo, Luca Morski, que dedica apenas poucas frases à viagem de navio em seu relato escrito em 1914, enfatiza as grandes dificuldades que testemunhou. Vejamos como ele registrou sua vinda:

Foi uma difícil travessia que durou mais ou menos três semanas. O bilhete gratuito para o Brasil tinha acabado em 1891. O preço das passagens era de $75 \mathrm{mil}$ réis para adultos e crianças de mais de 12 anos [...] Muitas pessoas morreram a bordo, especialmente crianças. As preces eram feitas sobre seus pequenos corpos e eles eram jogados no mar. De desespero, uma mulher tentou pular no mar atrás de sua criança e foi salva apenas por causa da rápida ação de um marinheiro (Morski 1914).

Relatos tão díspares acerca da viagem de navio rumo ao Brasil poderiam suscitar a hipótese de que essa diferença se deve ao fato de que, não tendo vindo no mesmo transporte, alguns migrantes passaram por experiências difíceis e outros não: ${ }^{14}$ Kobren e Cheutchuk teriam tido a sorte de ter uma viagem tranqüila e sem incidentes graves, enquanto Hotsailiuk e Morski, ao contrário, teriam sofrido ao testemunhar várias mortes ao longo de sua vinda para o Brasil.

Esta suposição, no entanto, é enganadora. De fato, em determinado ponto de seu tranqüilo relato, Kobren afirma:

Houve [no navio] mulheres que deram à luz. [...] esses tiveram ali sua alegria. Mas outros tiveram tristeza e choro. [...] Houve alguns que morreram. E esse evento enchia de tristeza não apenas os familiares, mas todos que viam tais funerais. O funeral se passava sem igreja, sem sacerdote, sem nenhum canto, o que não se vê em nossas aldeias. E o morto não era trazido para a sepultura, para a terra. Onde levavam o falecido: na água o jogavam! Agora ele iria jazer 
na água! O navio nem parou sua marcha! Navegou, como navegava. Como se fugisse da morte! Todos os que viam miraram longamente esse ponto, mas não viram nada além de água. Após o funeral, tristes e pensativos ainda amanheceram com a visão dessa cena nunca vista (Kobren 1935).

Assim, Kobren também experenciou a tragédia da perda de vidas em sua viagem de navio - um acontecimento que não era de modo algum incomum nessas viagens longas em navios superlotados e com más condições de higiene. Contudo, seu relato da viagem não está estruturado ao redor dessa tragédia, como ocorre nos testemunhos de Hotsailiuk e Morski. As mortes surgem apenas em um pequeno trecho de seu depoimento, enquanto muito mais espaço e energia são dedicados ao registro das descobertas e da curiosidade surgidas no confronto com um mundo novo. É claro que possivelmente tenham ocorrido variações nas condições de viagem entre um transporte e outro, mas não podemos deixar de levantar aqui a hipótese de que as diversidades desses depoimentos não se devem somente às diferenças de cada uma das viagens - ao fato de algumas levas de viajantes terem sofrido reveses maiores do que outras - mas também à distinção do olhar lançado sobre a experiência migratória, tanto no momento de sua ocorrência, quanto naquele em que ela era relatada.

Esta hipótese parece se confirmar quando comparamos o enfoque dos relatos de Kobren e Cheutchuk, por um lado, com os de Hotsailiuk e Morski, por outro, quando eles tratam de um outro assunto: a chegada ao Brasil e a estadia nas barracas de migrantes da Ilha das Flores e de Pinheiros. Estas barracas haviam sido construídas como alojamento provisório para os imigrantes de diferentes nacionalidades antes que eles chegassem às localidades onde seriam estabelecidos. Isto foi necessário porque, com o aumento expressivo do número de pessoas que vinha para o país, o governo viu-se em dificuldades para organizar o estabelecimento dessas levas sucessivas nas novas colônias: muitas vezes as terras às quais eles seriam destinados não estavam sequer demarcadas quando de sua chegada.

Tomemos em primeiro lugar o depoimento de Kobren. Ao tratar do momento em que seu navio chegou ao Brasil, seu relato segue no mesmo padrão de registro já empregado ao descrever sua viagem de navio: ele fala de suas descobertas e da curiosidade diante de um mundo novo. Em certo trecho, ele lembra dos marinheiros que colocavam as pessoas nas barcas, pegando-as no colo como se fossem leves: "pela primeira vez na minha vida eu via pessoas tão fortes". Na ida do navio até a terra, registra que:

em nossa barca começou uma viva conversa: Nova Terra, a cidade para a qual vamos, os navios ao nosso redor, pessoas diferentes e várias vozes, povos dife- 
rentes, fala que nunca escutamos, o próprio mar no qual deslizávamos — tudo nos deixava curiosos e era tópico de nossas conversas (Kobren 1935).

Ao chegar a terra, segundo Kobren, os moradores do Rio de Janeiro vinham tentar vender frutas para os migrantes, perguntando em português "Синьорис, кинь кер компрар ларанжас, бананас?" (ele escreve em alfabeto cirílico: "Senhores, quem quer comprar laranjas, bananas?"), e os migrantes lhes perguntavam em ucraniano: "Ha! O que eles dizem? E o que é aquela bonita ali? E quanto custa? E assim nos entendemos e compramos".

Novamente, percebe-se um contraste entre a fala de Kobren e o relato de Morski:

Ficamos um longo tempo na Ilha das Flores. Essa época foi terrível. As condições eram miseráveis, havia pouca comida e as pessoas morriam ao nosso redor. Havia um garoto que tocava sanfona para nos entreter. Outros brasileiros nos tentavam com comida e roupas (Morski 1914).

O mesmo evento, a venda de comida pelos brasileiros, é registrado por Morski como um problema, como uma "tentação" para os migrantes, que não deviam gastar ali seus recursos, e por Kobren como o contato com a novidade: novas frutas, novas pessoas, uma nova língua. Além disso, Morski cita em seu depoimento que a estadia nas barracas da Ilha das Flores foi uma "época terrível". De modo similar, Hotsailiuk, que ficou alojado em Pinheiros, conta:

Por volta das 12 horas o nosso trem chegou na estação de Pinheiro [...] Ali nós permanecemos três meses inteiros. Quem pode descrever ou contar pelo que passamos nesse lugar! Quantas pessoas dos nossos morreram [...] de febre amarela! Não foi uma vez em que houve 8 a 10 mortes diárias. Quanto choro, quantos gritos das mães atingidas pelo sofrimento. O desespero nos cobriu. Eu mesmo perdi dois filhos, Mehailo e Petró. Lembro de meu desespero e tristeza: vinha, porque ia conseguir uma terrinha para eles, e enquanto isso tinha que estabelecê-los em uma sepultura cinza, tão inocentes e tão jovens... (Hotsailiuk 1924).

Já Kobren registra sua estadia na mesma localidade de Pinheiros da seguinte forma:

Alguns jogavam cartas, alguns contavam histórias e outros escutavam, muitos já estavam deitados, mas poucos dormiam. [...] Em Pinheiro os nossos emigrantes 
estavam bem. Essas pessoas, que por toda a sua vida nunca haviam se conhecido bem, lá nesses dias comiam, bebiam, descansavam, em uma palavra, sem ansiedade celebravam. Sabiam que lhes dariam terras (Kobren 1935).

Do mesmo modo, Cheutchuk afirma sobre o período que passou em Pinheiros:

Nós observávamos com curiosidade as plantas brasileiras; alguns faziam flautas com bambu e as tocavam, para se divertir um pouco. Quando chegava o domingo, as pessoas iam sob uma árvore e cantavam canções sacras, porque já havia um longo tempo que não ouviam uma missa. De Gênova para cá, viajamos 3 semanas; ali, ficamos quase um mês todo, e ficamos um pouco acostumados a tudo ali (Cheutchuk 1936).

O mesmo padrão percebido nos relatos da viagem de navio repete-se no momento de descrever a chegada ao Brasil e a estadia nas barracas de migrantes: enquanto Kobren e Cheutchuk registram um processo ameno e de novas descobertas, Morski e Hotsailiuk nos passam imagens de morte e de dor. Como se explica que haja tamanha variação nas lembranças de uma migração feita na mesma época e em condições similares?

Uma primeira pista para essas variações pode ser encontrada no relato de Hotsailiuk, citado logo acima: ele tinha filhos, e perdeu-os na viagem. Já Kobren, a certo ponto da sua narração, afirma:

Neste lugar onde todos nós imigrantes fomos trazidos do Rio, paramos um pouco e observamos. Ele se chamava "Pinheiro" [Пінєйро], e nós, que há algumas semanas saíramos da Galícia, lemos a palavra "Pin-heiro" [Пінгейро, com $h$ aspirado], porque pensávamos que tinha que ler assim, e não do outro jeito. "Aqui é o tal Pin-heiro", era como os nossos pais o chamavam (Kobren 1935).

"Como os nossos pais o chamavam"! Kobren deixa entrever em sua fala uma informação que não tinha sido declarada até então: ele veio ao Brasil acompanhando seus pais. Estava isento, assim, da responsabilidade pelas decisões. Excitado com as novidades, não se preocupava com as incertezas envolvidas em uma mudança tão radical - largar sua terra e suas famílias para partir rumo a um lugar desconhecido, sob condições incertas.

Ao fazermos esta descoberta, percebemos que de fato Cheutchuk também veio com seus pais. ${ }^{15}$ Já Morski, assim como Hotsailiuk, veio com sua esposa e com dois filhos, contrariando a opinião do resto de sua família acerca da decisão de partir. 
Estes dados sugerem que há uma variação nos relatos acerca da vinda ao Brasil e, mais do que isso, que essa variação segue um padrão. No momento da experiência migratória, os elementos que são registrados por cada pessoa parecem variar de acordo com o seu momento no ciclo de vida e sua posição na configuração familiar. Este é um dos assuntos muito bem explorados por Maurice Halbwachs em seu livro La mémoire collective (1950). Segundo Halbwachs,

[...] homens que foram mantidos próximos pelas necessidades de uma obra comum [...] se separam em seguida em diversos grupos: cada um destes últimos é muito estreito para reter tudo o que ocupou o pensamento do [grupo] que os envolvia na época. Eles se prendem a um aspecto desse pensamento e apenas mantêm a lembrança de uma parte dessa atividade. Daí o surgimento de imagens diversas do passado comum que não coincidem, e dentre as quais nenhuma é verdadeiramente exata. [...] Quanto ao fato de que nós retemos a lembrança de impressões que nenhum de nossos companheiros, na época, pôde conhecer, $[\ldots]$ suponhamos que no momento em que partimos de viagem com uma sociedade de amigos, nós nos tenhamos encontrado sob a influência de uma viva preocupação, que eles ignoravam: absorvidos por uma idéia ou por um sentimento, tudo o que atingia nossos olhos ou nossos ouvidos se encontrava relacionado a essa preocupação: nós alimentávamos nosso pensamento interior com tudo aquilo que, no campo de nossa percepção, pudesse ser ligado a ela. [...] Se nós pensamos mais tarde nessa viagem, não se pode dizer que nos colocaremos no ponto de vista dos que a fizeram conosco. Eles mesmos serão lembrados apenas na medida em que suas pessoas podiam ser compreendidas no quadro de nossas preocupações (Halbwachs 1968 [1950]:12).

Algo similar ao que é discutido por Halbwachs ocorre nos depoimentos dos migrantes rutenos sobre sua vinda ao Brasil: de fato, podemos afirmar que ela era registrada de formas múltiplas por diferentes participantes já no instante em que ocorria: cada pessoa lançava um olhar específico sobre os eventos que a rodeavam.

Nós podemos, contudo, tentar atingir um grau de generalidade mais elevado para nossa hipótese — tentar fazê-la aplicável a um número maior de casos. Como observamos nesta situação, cada depoimento sobre o passado é diferente do outro. Tais variações, no entanto, seguem um padrão que não é só individual, apenas dependente das experiências anteriores de cada indivíduo. Como vimos, uma parte desses migrantes, os pais que tinham uma família sob a sua responsabilidade, eram muito mais sensíveis ao registro do sofrimento e das perdas humanas do que seus filhos. Para 
estes últimos, o olhar lançado aos eventos que os rodeavam não era limitado ou "enquadrado" pelas mesmas preocupações que sensibilizavam seus pais. Os depoimentos dos filhos nos dão acesso a informações e a detalhes das viagens que não eram registrados - e provavelmente sequer percebidos - por seus pais, cujo olhar estava extremamente sensibilizado pela apreensão dos acontecimentos que se coadunavam com suas preocupações maiores naquele momento.

Assim, é possível afirmar que esses pais tinham olhares similares em relação ao que se passava na viagem ao Brasil se contrastados com os olhares de seus filhos - que, por sua vez, tinham olhares da mesma natureza. Ou seja, se uma dada lembrança é tributária do olhar possível de ser lançado sobre o evento na época em que ele ocorreu, podemos levantar aqui a hipótese de que este olhar foi modulado de acordo com a posição que cada pessoa ocupava na configuração social em que estava inserida, e que suas lembranças serão tributárias das características estruturais ligadas à tal posição. A condição de produção de inflexões nas lembranças que observamos aqui em ação pode ser definida da seguinte forma: a posição que um determinado sujeito ocupa em uma configuração social é um dos fatores que geram diferenças e semelhanças na produção e no relato de lembranças. Pessoas que ocupam posições semelhantes em uma dada configuração social têm suas lembranças infletidas em uma mesma direção, pois observaram o evento original estando sujeitas a constrangimentos similares.

Vemos assim que a "memória" da migração não é um bloco homogêneo, uma "memória coletiva" compartilhada por todos os rutenos que vieram ao Brasil, e que um dos motivos geradores de heterogeneidade nas lembranças dos migrantes é o fato de cada um deles ter feito um registro de sua vinda a partir da posição que então ocupava na configuração social em que estava inserido.

\section{O passado em movimento}

Outro motivo gerador de heterogeneidades nas lembranças surge com clareza no relato de Pelep Kobren. Seu parco interesse por assuntos que não diziam respeito à sua posição de filho na época da migração, implícito ao longo de todo o seu depoimento, torna ainda mais intrigante seu registro da partida de sua aldeia, ainda na Galícia, pois esse registro foge ao olhar de um garoto de 14 anos, que estrutura a quase totalidade de suas lembranças. Ao contar o momento da partida, ele afirma: 
E foram para o Brasil, para que ao menos suas crianças ficassem em boa situação. E foram com suas crianças para a meta, deixaram suas terras e ficaram cada um de seu lado, os pais e velhinhos de 70 ou 80 anos viveram o resto de seus dias e, quando morreram, enterraram-nos pessoas estranhas. [...] E fizeram bem esses filhos, que deixaram seus pais e nada sabem deles, onde estão e o que fazem? A esta questão deveis responder vós, senhor leitor! (Kobren 1935).

Este trecho surge quase como uma intromissão em seu relato. Escrito em terceira pessoa, aborda uma questão relacionada à vinda para o Brasil a partir de um ponto de vista exterior: aqui, Kobren não se inclui entre os migrantes, e fala dos rutenos que abandonaram seus pais sem incluir-se entre eles. Este comentário mistura-se às suas lembranças a respeito do que ocorrera quarenta anos antes com ele; Kobren enfoca em 1936 um assunto que dificilmente passaria por sua cabeça na época em que migrou, tantos anos antes. No momento em que estrutura seu passado em um depoimento, seu presente faz uma intromissão espontânea no caminho de suas lembranças - pois era o Kobren adulto, um senhor de 54 anos de idade, que abordava aqui a problemática do destino dos "pais e velhinhos de 70 ou 80 anos", e não o Kobren migrante, com 14 anos. Neste ponto do relato, sua situação contemporânea interfere em sua relação com o passado, e força o surgimento de uma "lembrança" antes inexistente, uma reflexão que é produto de um jogo entre o garoto que ele foi em 1896 e o adulto que é quarenta anos depois.

Podemos aqui imaginar que se ele escrevesse seu relato vinte anos antes, ou vinte anos mais tarde, outras seriam as questões presentes a interferir em seu registro do passado. Ou seja, estamos aqui diante de outra condição propícia para a inflexão das lembranças: aquilo que uma pessoa é capaz de registrar de seu passado em um certo momento de sua vida não é tributário apenas do olhar lançado em face da experiência original, no momento em que ela ocorreu; seu registro é também modulado por questões do presente, o que quer dizer que a cada instante no presente o passado se encontra um pouco modificado. Para uma pessoa, o registro do passado não é como um registro gravado em uma fita magnética ou na memória do computador que, ao ser feito, é definido de uma vez por todas e jamais se altera. Ao contrário, a lembrança que uma pessoa evoca em um dado instante de sua existência deve parte de sua substância ao registro que foi feito no passado, e parte à situação atual, que inflete a lembrança anterior em um sentido específico consistente com esta ocorrência de agora. Nós, leitores, temos acesso a uma visão desse passado que é uma combinação do seu registro original com uma percepção contemporânea do relato que nos é feito. 
O presente insidia também de outras formas nas narrativas dos migrantes. Ao lermos a carta escrita por Teodor Pototskei em 1897, um ano após sua chegada ao Brasil, notamos que suas experiências são contadas com um grau de detalhamento que, mais tarde, seria perdido. A descrição que Pototskei faz de uma nova fruta que descobriu no Brasil, a banana, é plena de frescor:

[Nossos rutenos] plantam aqui no Paraná as bananas. Isso parece uma vagem da Galícia, tem uma concha igual sobre ela. No meio, quando separa essa concha, é tão macio, e muito doce, e dá pra esmagar em cima do pão, já que é macio, e é muito saboroso comer pão com essas bananas (Pototskei 1897).

Eis um tipo de detalhe que está ausente dos relatos feitos anos mais tarde. Após algumas décadas, uma banana jamais seria descrita da mesma forma - ou, talvez, sequer descrita, pois seria parte integrante da vida cotidiana e teria se tornado, de certo modo, invisível.

Em contrapartida, nos relatos produzidos mais tarde, são outros os detalhes que ganham relevo. Ao contar sobre a sua chegada a Pinheiro, por exemplo, Kobren faz questão de registrar: "Foi aqui que pela primeira vez vimos as 'vendas' daqui". Ora, ao chegarem, os migrantes estavam diante de um mundo completamente novo, e não tinham ainda noção do que nele seria relevante e do que seria secundário. As "vendas" — os pequenos comércios das colônias - seriam fundamentais posteriormente no estabelecimento dos migrantes no Brasil, mas eles saberiam disso somente depois. Assim, ao contar o passado, Kobren dá ênfase a detalhes que apenas assumiram importância mais tarde. Em outras palavras: aquilo que é enfatizado como uma informação importante no relato do passado muitas vezes apenas passou a ser visto como importante em um momento posterior àquele em que o fato relatado foi vivido. Novamente, se Kobren escrevesse sua história em 1896, quando migrou, a "venda" dificilmente apareceria da mesma forma em seu depoimento.

Com o passar dos anos, os detalhes do cotidiano são apagados, e coisas que eram pouco relevantes no início da migração - como as "vendas" tomam o primeiro plano do relato. Dessa forma, a lembrança atual não é nem o que aconteceu no passado, nem uma pura invenção do presente, mas o produto de uma combinação destes dois fatores. Nas palavras de Halbwachs,

a lembrança é em grande medida uma reconstrução do passado com a ajuda de dados emprestados do presente, e preparada além disso por outras reconstruções 
feitas em épocas anteriores e de onde a imagem do passado já saiu bastante alterada (Halbwachs 1968 [1950]:57).

Assim, quem se lembra de um evento do passado em um dado instante de sua vida produzirá significados novos para ele de acordo com sua situação presente, gerando, de fato, um passado novo a cada instante - um passado em movimento.

\section{Conclusão}

No presente artigo, vimos como as lembranças do passado emitidas por indivíduos pertencentes a uma dada configuração estão sujeitas a inflexões geradas socialmente. Por um lado, o emprego de categorias e de esquemas de percepção compartilhados está ligado ao que poderíamos chamar de uma "regulação social das lembranças", mecanismo que implica o surgimento de elementos comuns em recordações do passado produzidas por quem participa de uma dada configuração social em certo momento. Ao mesmo tempo, contudo, outras condições sociais agem no sentido de infletir essas lembranças em sentidos divergentes, o que nos leva a afirmar a inexistência de uma "memória coletiva" unívoca, como defendia Maurice Halbwachs em sua obra: de fato, como observamos no caso dos relatos dos imigrantes rutenos acerca de sua vinda para o Brasil, lembranças de eventos passados vividos conjuntamente apresentam tanto elementos divergentes quanto elementos convergentes. Uma análise completa da produção de reminiscências em textos de arquivo deveria ainda incluir um estudo das inflexões ligadas aos regimes discursivos próprios à criação de uma narrativa escrita, tarefa que aqui não desenvolveremos por falta de espaço.

Cabe por fim destacar que, apesar de termos utilizado aqui material de arquivo, o presente estudo acerca da produção de lembranças tem conseqüências que mereceriam ser melhor exploradas em relação aos dados obtidos na atividade etnográfica. Boa parte do material coletado por um antropólogo em seu trabalho de campo tem como fontes depoimentos orais fornecidos por seus interlocutores. Nosso estudo chama a atenção para o fato de que as versões do passado construídas por esses interlocutores envolvem uma multiplicidade de sentidos e de significações que podem se dever à ação de certas condições sociais que geram divergências na reconstrução das lembranças. Dentre elas, destacamos aqui as variações nas recordações de acordo com a posição que cada pessoa ocupa nas configurações em que está inserida e a sua reelaboração com o passar do tempo. Por outro lado, 
as convergências entre diferentes depoimentos não equivalem necessariamente a uma confirmação de que aquilo que é relatado sobre o passado é "verdadeiro", mas podem chamar a atenção para o fato de que a percepção dos eventos passados é constituída por um determinado grupo a partir de categorias e esquemas de percepção compartilhados por seus membros.

Recebido em 05 de novembro de 2007

Aprovado em 13 de fevereiro de 2008

Paulo Renato Guérios é doutor em Antropologia Social pelo Museu Nacional/UFRJ; professor titular da Universidade Positivo. E-mail: <pguerios@ig.com.br> 


\section{Notas}

${ }^{1}$ Alguns exemplos paradigmáticos são as análises de Pierre Nora (1997 [1984]) acerca da constituição de "lugares de memória"; o estudo do recrudescimento do "dever de memória" dos judeus a respeito da Shoah, que levou à criação de uma verdadeira vaga de estudos sobre a memória na França (Zonabend 1999); ou o acompanhamento dos movimentos de construção e afirmação identitária entre grupos minoritários, como ocorre com os "remanescentes de quilombos" no Brasil (e.g., em Arruti 1997).

${ }^{2}$ Isto não equivale a dizer que a obra de Halbwachs tenha sido ignorada ou lida acriticamente por todos os estudiosos que tomaram a "memória" como objeto de estudo. Além dos trabalhos críticos de Bloch (1925), Bastide (1970) e Namer (1987), a que nos referiremos a seguir, pesquisadores como Confino (1997), Lavabre (1998) e Marcel (1999) fizeram avaliações críticas das contribuições de Halbwachs, enquanto Pollak (1990), Sabourin (1997), Zonabend (1999), para mencionar apenas alguns trabalhos de relevância, aplicaram e levaram adiante suas idéias.

${ }^{3}$ Este trabalho apóia-se em minha tese de Doutoramento em Antropologia Social (Guérios 2007).

${ }^{4}$ Rutenos (die Ruthenien) era o termo utilizado pelas autoridades do Império Austro-Húngaro para designar a população de religião uniatista que vivia no extremo oriental de suas terras. A designação vem de ruteni, termo em latim referente à palavra nativa rucêne (русини, "habitantes de Rus'"). Rucêne foi o termo criado pela cúria papal para referir-se aos povos católicos eslavos após a União de Brest (1596), que os transformou em católicos uniatas, ou seja, católicos de rito oriental que respondem à autoridade do papa romano. Após a Primeira Guerra Mundial, devido à ação dos nacionalistas que buscavam a independência desse território sob o nome de "Ucrânia", esta população passou a adotar a denominação "ucranianos" (cf . Guérios 2007:189-226).

${ }^{5}$ Halbwachs era ligado ao grupo que se constituiu em torno de Émile Durkheim, a chamada "Escola Sociológica Francesa". Tendo ingressado na École Normale Supérieure em 1898, foi aluno de Henri Bergson, o que deixou marcas duradouras em sua obra. Defendeu em 1909 teses em direito (A expropriação e o preço dos terrenos em Paris de 1880 a 1900) e em 1913 em letras (A classe trabalhadora e os níveis de vida). A seguir, foi professor de sociologia na Faculdade de Letras de Strasbourg (de 1919 a 1935) e na Sorbonne (1938-1944), tendo passado também um ano no departamento de sociologia da Universidade de Chicago (1930). Em 1944, foi eleito para o Collège de France na cadeira de Psicologia Coletiva, e faleceu no ano seguinte em um campo de concentração.

${ }^{6}$ Cf. a exposição de Jean Duvignaud na introdução a Les cadres sociaux de la mémoire (Halbwachs 1976[1925]:viii). 
${ }^{7}$ Como nosso objeto de estudo, aqui definido, não é "a memória", e como a ênfase deste trabalho é na pesquisa empírica e não no debate teórico, remeto os leitores que desejarem ter contato com tais questões ao trabalho de Myrian Sepúlveda dos Santos, "Memória coletiva e teoria social" (2003). Nele a autora apresenta o modo como a "memória social" foi abordada por autores tão diversos quanto Maurice Halbwachs, Frederic Bartlett, os estudiosos da Escola de Frankfurt e filósofos como Bergson, Derrida e Foucault.

${ }^{8}$ Quando um visitante chega a Prudentópolis, a presença de elementos étnicos ucranianos é imediatamente perceptível. Após passar sob o portal ornado de cúpulas bizantinas, instalado no principal acesso à sede da cidade em comemoração ao centenário da imigração ucraniana em 1995, os dois maiores edifícios que ocupam seu campo de visão são o Seminário São José e, logo atrás dele, a portentosa Igreja Matriz de São Josafat, de rito católico oriental. A Matriz está localizada em frente à praça Tarás Chevtchenko, onde está uma estátua do poeta nacionalista ucraniano e o Museu do Milênio, em que são expostos objetos dos primeiros migrantes. Caso esse visitante se dirija a alguma das 32 colônias (chamadas de "linhas") que circundam a sede da cidade, ele perceberá que também nelas a maior construção é uma igreja ou capela com as mesmas cúpulas bizantinas. Em 2002, segundo dados da Eparquia Ucraniana de São João Batista (EPARQUIA 2002), existiam no total 36 igrejas e capelas ucranianas de rito oriental no Município, muitas delas de tamanho e sofisticação comparáveis à da Matriz. Apesar de a sede da Eparquia Ucraniana de São João Batista ter sido transferida para Curitiba na década de 1970, Prudentópolis continua sendo o grande centro da Igreja Católica Ucraniana no Brasil. Em 2003, dos 72 padres da ordem greco-católica dos basilianos residentes no Brasil, 17 moravam em Prudentópolis, enquanto Curitiba, a segunda cidade com mais padres ucranianos, contava com nove sacerdotes (EPARQUIA 2002).

${ }^{9}$ A palavra "colônia", no sul do Brasil, "é mais do que um referente territorial e socioeconômico: designa, de fato, a comunidade étnica" (Seyferth 2003:150, n.8). De modo similar, a categoria "colono" nessa região é indissociável da imagem de um "camponês pequeno proprietário 'de origem'", sendo assim geralmente articulada a um qualificador étnico (Seyferth 1996:33, n.7).

${ }^{10}$ A análise sociológica detalhada da produção destes textos e de outros materiais, produzidos em diferentes momentos por sacerdotes e por intelectuais rutenos e poloneses, são analisados na versão completa deste estudo (Guérios 2007).

${ }^{11}$ Os dados dos censos promovidos por Viena nos traçam um perfil dos rutenos galicianos no final do século XIX, em comparação com o perfil dos poloneses que ali viviam: em toda a região da Galícia, 33\% dos poloneses e apenas $6 \%$ dos rutenos trabalhavam fora da agricultura; na principal cidade da Galícia, Lviv, apenas 7\% da população era rutena. As políticas educacionais mantiveram os rutenos sem acesso à educação: enquanto em todo o Império Austro-Húngaro (excluindo a Galícia) em média 75\% das crianças freqüentavam escolas primárias, apenas 15\% das crianças rutenas o faziam (Himka 1984:16); em 1880, o censo apontava que somente 10\% das mulheres e 17\% dos homens galicianos não eram analfabetos (Himka 1988); em 
toda a Galícia, havia apenas uma escola secundária em língua rutena (Rudnytsky 1987:316); dos poucos rutenos que ingressavam na Universidade de Lviv, 55\% cursavam a faculdade de teologia, enquanto apenas $9 \%$ dos poloneses o faziam (Himka 1986:4, 5). Finalmente, o vice-rei da Galícia e seus quadros administrativos sempre eram apontados entre os membros da aristocracia polonesa.

${ }^{12}$ De fato, essa oposição é viva ainda hoje entre os descendentes dos migrantes, que lançam mão dela a todo o momento em suas interações cotidianas. As implicações da existência de categorias compartilhadas em cada configuração social tornaram-se uma questão clássica na disciplina da antropologia, presente desde os textos fundadores de Durkheim e Mauss (1903); Durkheim (1912). No primeiro, eles afirmam que os homens precisam colocar ordem no universo, e que o fazem por meio de categorias classificatórias; a partir do segundo, tendo como interlocutores os filósofos neokantianos, Durkheim e seus seguidores desenvolveram estudos sobre cada uma das categorias clássicas do entendimento humano para demonstrar o caráter social de sua construção (cf Oliveira 1993). O conceito de categoria foi apropriado de diferentes formas por estudiosos do porte de Evans-Pritchard (em seu trabalho sobre as categorias de tempo e espaço entre os Nuer); Lévi-Strauss (que em O pensamento selvagem vê a lógica classificatória como o fundamento estruturante de todo e qualquer pensamento); ou Edmund Leach (que em Sistemas políticos da Alta Birmânia estudou detidamente como os nativos se apropriavam das categorias em que se dividiam — chan, kachin — e dentro desta última, gumsa e gunlao).

${ }^{13}$ A expressão "esquemas de percepção" foi proposta por Pierre Bourdieu em Le sens pratique (1980).

${ }^{14}$ Esta hipótese é usual em estudos sobre a migração. Thales de Azevedo (1982:137-140), por exemplo, quando contrapõe os depoimentos dos migrantes italianos que vieram para o Rio Grande do Sul na mesma época em que os rutenos, afirma: "Os regulamentos oficiais em vigor [sobre o transporte] previam os requisitos de relativo bem-estar, de alimentação suficiente e sadia, de bastante espaço para cada viajante da $3^{\mathrm{a}}$ classe e do número total de emigrantes a bordo. [...] mas essas condições, umas vezes, eram preenchidas, outras, inteiramente burladas dando lugar a mortes, contágio, mau passadio, a grande sacrifício dos viajantes durante os dezesseis ou mais dias do percurso" [ênfase minha].

${ }^{15}$ No início de seu relato, Cheutchuk conta: "eu e meu irmão íamos à escola, e exatamente nessa época começaram as férias. Um dia, veio meu pai e trouxe para nós uma novidade inesperada: que nós partiríamos para o Brasil. Explicou-nos que tínhamos que ir para outro país, procurar um melhor destino e a alegria, porque ali não estava bem, havia miséria e não havia para quem trabalhar. Nós, de alegria, até pulamos!" (Cheutchuk 1936). 


\section{Referências bibliográficas}

ARRUTI, José Maurício. 1997. "A emergência dos 'remanescentes': notas para o diálogo entre indígenas e quilombolas". Mana. Estudos de Antropologia Social, 3(2):7-38.

AZEVEDO, Thales. 1982. Italianos e gaúchos. Os anos pioneiros da colonização italiana no Rio Grande do Sul. Rio de Janeiro: Ed. Cátedra.

BASTIDE, Roger. 1970. "Mémoire collective et sociologie du bricolage". L'Année Sociologique, 21:85-108.

BLOCH, Marc. 1925. "Mémoire collective, tradition et coutume, à propos d'un livre récent". Revue de Synthèse Historique, XL(118-120):73-83.

BOURDIEU, Pierre. 1980. Le sens pratique. Paris: Les Editions de Minuit.

CHEUTCHUK, M. 1936. Depoimento ao jornal ПРАЦЯ. Прудинтопіль: Видавництво оо. Василіян [Pratsia. Prudentópolis: Tipografia dos padres basilianos].

CONFINO, Alon. 1997. "Collective memory and cultural history: problems of method". American Historical Reveiw, 105:1386-1403.

DURKHEIM, Emile. 1968 [1912]. Les formes élémentaires de la vie religieuse. Le système totémique en Australie. $5^{\text {eme }}$ éd. Paris: PUF.

· \& MAUSS, Marcel. 1968 [1903]. “De quelques formes primitives de classification". In: M. Mauss. Oeuvres, v. 2. Paris: Minuit. pp. 13-89.

EPARQUIA Ucraniana de São João Batista. "Relatório sobre as atividades das paróquias e missões referente ao ano de 2002". Ms.

EVANS-PRITCHARD, Edward. 1978. Os

Nuer. São Paulo: Perspectiva.-

GUÉRIOS, Paulo Renato. 2007. Memória, identidade e religião entre imigrantes rutenos e seus descendentes no Pa- raná. Tese de doutoramento, PPGAS/ Museu Nacional/ UFRJ.

HALBWACHS, Maurice. 1968 [1950]. La mémoire collective. Paris: PUF.

- 1976 [1925]. Les cadres sociaux de la mémoire. Paris: Mouton.

HARTOG, François \& REVEL, Jacques. 2001. Les usages politiques du passé. Paris: Éd. de l'EHESS.

HIMKA, John Paul. 1984. "Serfdom in Galicia". Journal of Ukrainian Studies, 9(2):3-28.

- 1986. "Priests and peasants: the greek catholic pastor and the Ukrainian National Movement in Austria, 18671900". Canadian Slavonic Papers, 21:1-14.

- 1988. Galician villagers and the ukrainian national movement in the $19^{\text {th }}$ century. Edmonton: The Canadian Institute of Ukrainian Studies.

HOTSAILIUK, A. 1924. Depoimento ao jornal ПРАЦЯ. Прудинтопіль: Видавництво оо. Василіян [Pratsia. Prudentópolis: Tipografia dos padres basilianos].

KOBREN, P. 1935. Depoimento ao jornal ПРАЦЯ. Прудинтопіль: Видавництво оо. Василіян [Pratsia. Prudentópolis: Tipografia dos padres basilianos].

LAVABRE, Marie Claire. 1994. Le fil rouge. Sociologie de la mémoire communiste. Paris: Presses de la Fondation Nationale des Sciences Politiques. - 1998. "Maurice Halbwachs et la sociologie de la mémoire". Raison présente, 128:47-56.

LEACH, Edmund. 1996 [1954]. Sistemas políticos da Alta Birmânia. São Paulo: Edusp.

LÉVI-STRAUSS, Claude. 1989 [1962]. O pensamento selvagem. São Paulo: Papirus. 
MARCEL, Jean-Claude. \& MUCCHIELLI, L. 1999. "Un fondement du lien social: la mémoire collective selon Maurice Halbwachs". Technologies. Idéologies. Pratiques. Revue d'anthropologie des connaissances, 13(2):63-88.

MORSKI, L. 2000 [1914]. "Relato autobiográfico". In: J. P. Morski (org.), Under the Southern Cross. A collection of accounts and reminiscences about the ukrainian immigration in Brazil, 1891-1914. Winnipeg: Watson \& Dwyer Publishing.

MUZEKA, P. 1936. Depoimento ao jornal ПРАЦЯ. Прудинтопіль: Видавництво оо. Василіян [Pratsia. Prudentópolis: Tipografia dos padres basilianos].

NAMER, Gerard. 1987. Mémoire et société. Paris: Meridiens Klincksieck.

NORA, Pierre. 1997 [1984]. Les lieux de mémoire. (3 vols). Paris: Gallimard (Éd. Quarto).

OLIVEIRA, Luiz Roberto Cardoso. 1993. "As categorias do entendimento humano e a noção de tempo e espaço entre os Nuer". Série Antropologia, 137.

PACEVITCH, I. 1951. Artigo publicado no jornal ЦВІРКУН. Прудинтопіль: Видавництво оо. Василіян [Tzvirkun. Prudentópolis: Tipografia dos padres basilianos].

POLLAK, Michael. 1990. L'expérience concentrationnaire. Essai sur le maintien de l'identité sociale. Paris: Ed. Métaillé.

POTOTSKEI, T. 1897. Carta aos imigrantes ucranianos nos EUA. Reproduzido no jornal ЦВІРКУН. Прудинтопіль: Видавництво оо. Василіян [Tzvirkun. Prudentópolis: Tipografia dos padres basilianos].

PRITSAK, Omeltjan. 1981. "Kievan Rus'and the Sixteenth-Seventeenth Century Ukraine". In: I. Rudnytsky (org.), Rethinking ukrainian history. Edmonton: The Canadian Institute of Ukrainian Studies. pp 1-28.
RUDNYTSKY, Ivan. 1987. "The ukrainians in Galicia under austrian rule". In: Essays in modern ukrainian history. Ontario: Un. of Toronto Press. pp. 315-352.

SABOURIN, Pierre. 1997. "Perspective sur la mémoire sociale de Maurice Halbwachs". Sociologie et sociétés, XXIX(2):139-161.

SANTOS, M. S. 2003. Memória coletiva e teoria social. São Paulo: Annablume.

SEYFERTH, Giralda. 1996. "Etnicidade e cultura: a constituição da identidade teuto-brasileira". In: G. C. Zarur (org.), Etnia e nação na América Latina. Washington: OEA. pp.17-36. . 2003. "Estudo sobre reelaboração e segmentação da identidade étnica". In: P. Scott \& G. Zarur (orgs.), Identidade, fragmentação e diversidade na América Latina. Recife: Ed. Universitária da UFPE. pp.147-183.

YERUSHALMI, J. 1984. Zakhor. Histoire juive et mémoire juive. Paris: Éd. de la Découverte.

ZONABEND, F. 1999. La Mémoire longue. Temps et histoires au village. 2. ed. Paris: Ed. Jean-Michel Place. 


\section{Resumo}

O presente artigo propõe um enfoque para o estudo das relações entre "memória" e pertencimento social. A partir de uma crítica dos objetivos e dos instrumentos propostos nas obras de Maurice Halbwachs acerca da "memória coletiva", enceta uma discussão sobre as condições sociais que infletem a produção de lembranças entre pessoas ligadas a uma dada configuração social. São utilizadas como material empírico as lembranças produzidas por imigrantes camponeses de origem eslava - os "rutenos" ou "ucranianos" - a respeito de sua vinda ao Brasil no final do século XIX. O artigo inicia com um estudo crítico das idéias de Halbwachs sobre as relações entre "memória" e "sociedade"; após uma breve apresentação dos imigrantes ucranianos, explora seus relatos em torno de sua imigração para discutir os mecanismos sociais que incidem em suas lembranças em sentidos convergentes ou divergentes entre si; e conclui-se com o exame de algumas implicações da análise empreendida.

Palavras-chave Memória coletiva, Ucranianos, Brasil, Memória social, Maurice Halbwachs, Imigração

\section{Abstract}

This article seeks to put into focus the study of the relationship between "memory" and social belonging. Beginning with a critique of the objectives and tools advanced in Maurice Halbwachs's writings on "collective memory", the article embarks on a discussion of the social conditions that inflect upon the production of memories among people linked to a given social configuration. The empirical bases for the analysis are the recollections produced by peasant immigrants of Slavic origin - the "Rusyns" or "Ukrainians" - concerning their journey to Brazil in the end of the nineteenth century. The article starts with a critical study of Halbwachs's ideas on the relationship between "memory" and "society", and, after a brief presentation of the Ukrainian immigrants, explores the stories concerning their migrations in order to discuss the social mechanisms that impress upon their recollections meanings that both converge or diverge amongst themselves. It concludes by an examination of some of the implications of the analysis.

Key words Collective memory, Ukrainians, Brazil, Social memory, Maurice Holbwachs, Immigration 